UDC 612.017.1

doi: https://doi.org/10.15407/ubj90.04.080

\title{
EFFECT OF TRIFLUOROETHANOL ON ANTIBODY REACTIVITY AGAINST CORRESPONDING AND NONRELATED ANTIGENS
}

\section{S. A. BOBROVNIK, M. O. DEMCHENKO, S. V. KOMISARENKO}

\author{
Palladin Institute of Biochemistry, National Academy of Sciences of Ukraine, Kyiv;
} e-mail: s-bobrov@ukr.net

The ability of antibodies to switch between specific and nonspecific recognition of antigens under various factors is the key issue. Here we demonstrate that 2,2,2-trifluoroethanol (TFE) is one of these factors influencing the ability of monoclonal antibodies to react specifically with corresponding antigen (ovalbumin) and transforming them into polyreactive immunoglobulins (PRIGs) that are strong but nonspecific binders with various antigens. Such switching of antibody reactivity is a nonlinear and even nonmonotonous function of TFE concentration and depends strongly on incubation time and temperature. At room temperatures $\left(25^{\circ} \mathrm{C}\right)$ the specific antibodies under $30 \%$ TFE action are transformed into PRIGs. However, at $0{ }^{\circ} \mathrm{C}$ the variation of antibody reactivity is complicated. TFE is known as the alcohol with one of the strongest proton-donor abilities in hydrogen bonding and its effect is probably in binding to specific sites that switch the antibody recognition ability.

Ke ywords: specific monoclonal antibodies; polyreactive immunoglobulines; antibody-antigen interaction; 2,2,2-trifluoroethanol; antibody affinity.

$\mathrm{E}$ arlier we have shown [1], that the nonspecific reactivity of serum immunoglobulins against different antigens may be strongly increased when they were incubated for $5-10 \mathrm{~min}$ at $20-30{ }^{\circ} \mathrm{C}$ at extreme (low or high) $\mathrm{pH}$ values or after treatment by high concentrations of chaotropic ions, such as 3.0-5.0 M solutions of KSCN. Later our data were supported by other studies [2,3]. A similar effect on serum immunoglobulins of human, mouse, rabbit, bovine, etc., were also observed on treatment with $30-50 \%$ ethanol or exposure for $5-10 \mathrm{~min}$ to high temperature, $58-61{ }^{\circ} \mathrm{C}$ [1]. It was established [4] that such effect was caused by transformation of various specific antibodies into nonspecific, the so called polyreactive immunoglobulins (PRIGs) that attain the ability to interact with various nonrelated antigens.

It was also found that similarly transformed antibody molecules are the natural constituents in serum of intact people and animals, so that their amount increases in species of old age [5]. The established fact that introduction of PRIGs to experimen- tal animals possessing Lewis carcinoma leads to enhancing of malignant tissue growth [6] indicates the possibility of their involvement in some pathologies. All that makes further studies of the mechanism of PRIGs transformation under the influence of various factors quite actual.

Fluorinated alcohol 2,2,2-trifluoroethanol (TFE) is known as potent modifier of protein structure that is frequently used in biochemistry and structural biology. Possessing strong $\mathrm{H}$-bonding proton-donor ability it can affect the protein conformation in a very special way, by disrupting the intramolecular $\mathrm{H}$-bonds even at very low concentrations $[7,8]$. At higher concentrations TFE can be used as a denaturant of quaternary structure, weakening hydrophobic interactions within or between molecules in solution [9]. It is known that TFE can induce secondary structure of small peptides by favoring the formation of $\alpha$-helices or even $\beta$-sheet content $[9,10]$. Stabilizing $\beta$-hairpin structures $[11]$ it can induce amyloid-like fibril formation $[12,13]$.

(C) 2018 Bobrovnik S. A. et al. This is an open-access article distributed under the terms of the Creative Commons Attribution License, which permits unrestricted use, distribution, and reproduction in any medium, provided the original author and source are credited. 
It is supposed that studies with alcohols such as TFE, have become a valuable tool for probing biomolecular structure, function and dynamics of macromolecules. All this was the reason that we decided to study how TFE can affect on the reactivity of monoclonal antibodies against corresponding and structurally nonrelated antigens. The results of these studies are presented in this paper.

\section{Materials and Methods}

Antigens and antibodies. In this study we used hen egg albumin (ovalbumin), bovine serum albumin (BSA) and horse skeletal muscle myoglobin (HSMM) as antigens from Sigma, USA. Mouse monoclonal antibodies (mAbs) specific to ovalbumin were also obtained from Sigma (USA). 2,2,2-trifluoroethanol (TFE) was purchased from Fluka.

ELISA. The amount of antibodies or nonspecific polyreactive immunoglobulins (PRIGs) that were bound to antigens immobilized on immunological plates we evaluated using enzyme liked immunosorbent assay (ELISA). In order to evaluate the antiovalbumin mAbs activity by ELISA, ovalbumin was coupled to 96-cell NUNC immunological plates by incubation of ovalbumin solution $(10 \mathrm{mg} / \mathrm{ml})$ in $1 \%$ of $\mathrm{NH}_{4} \mathrm{HCO}_{3}+0.01 \% \mathrm{NaN}_{3}$ at $4{ }^{\circ} \mathrm{C}$ during 20-24 h. Directly before using these plates, the ovalbumin solution was removed and the plates were washed three times with phosphate buffered ( $\mathrm{pH}$ 7.2) physiological solution $\mathrm{NaCl}$ (PBS) + 0.1\% Twin 20 (TBS) .

In order to determine the binding of nonspecific PRIGs to immobilized antigen by ELISA, NUNC plates were covered with BSA or horse myoglobin by the method described by us earlier. Briefly, solutions of BSA or horse myoglobin ( $1 \mathrm{mg} / \mathrm{mg})$ in $1 \%$ solution of $\mathrm{NH}_{4} \mathrm{HCO}_{3}+0.01 \% \mathrm{NaN}_{3}$ was dried at $37^{\circ} \mathrm{C}$ during $15-20 \mathrm{~h}$. Immediately before using, the plates were carefully washed at first with running water and then with TBS buffer.

To determine the amount of either mAbs or PRIGs bound to immobilized antigen the plates were incubated with horseradish peroxidase-conjugated goat anti-mouse IgG antibodies (Sigma, USA) during $60 \mathrm{~min}$ at $4{ }^{\circ} \mathrm{C}$. Then the unbound conjugates were carefully washed away, and peroxidase substrate - the solution of orthophenilendiamine $(1 \mathrm{mg} /$ $\mathrm{ml})$ in $0.01 \mathrm{M}$ phosphate buffer, $\mathrm{pH} 5.0$ and $0.003 \%$ $\mathrm{H}_{2} \mathrm{O}_{2}$ solution - were added. After color developing the reaction was stopped by adding $50 \mu \mathrm{l}$ of $2 \mathrm{M}$ sulfuric acid per well, and optical density was measured by microphotocolorimeter ELx800 (BIO-TEK) at $490 \mathrm{~nm}$.
It is necessary to note, that at sufficiently high dilution the solutions of antibodies or PRIGs, their amount coupled to adsorbed antigen is directly proportional to the concentrations of these reagents in studied samples. Also, in these conditions the color developed in plate wells obtained by ELISA is directly proportional to the amount of the antibodies bound to immobilized antigen. Due to this reason it is possible to use the optical density in ELISA wells for calculation of the kinetic parameters for antigenantibody reaction instead of real antibody concentrations in study samples.

The study of THF effect on mAbs reactivity. The commercial anti-ovalbumin mAbs were diluted 1:25 in PBS, stored at $4{ }^{\circ} \mathrm{C}$ and used in all further experiments. In order to study the THF effect on $\mathrm{mAbs}$ reactivity, different concentrations of TFE were prepared in PBS buffer and, before use, these aliquots were incubated at desired temperature $\left(0^{\circ} \mathrm{C}\right.$ or $25^{\circ} \mathrm{C}$ ). Then $5 \mu \mathrm{l}$ of anti-ovalbumin antibodies was added to $200 \mu \mathrm{l}$ of THF solution either at $0^{\circ} \mathrm{C}$ or at $25^{\circ} \mathrm{C}$ and incubated for certain time. After the incubation, $10 \mu \mathrm{l}$ of the mixture was transferred into $5 \mathrm{ml}$ of PBS, and then half of this mixture was diluted $1: 4$ with TBS. The samples of non-treated antibodies serving as controls were diluted in the same way, but in this case PBS was used instead of TFE solution.

The antibody samples, either control or TFEtreated and then diluted $1: 50$ by PBS were transferred to plates with adsorbed BSA or horse myoglobin to determine the PRIGs activity. These plates were incubated for $1 \mathrm{~h}$ at $37^{\circ} \mathrm{C}$ (i.e. in optimal conditions for PRIGs binding) for the measurements of PRIGs activity that was generated in TFE solutions. After additional dilution 1:4 in TBS, the samples were transferred to plates covered with ovalbumin and these plates were incubated for $1 \mathrm{~h}$ at $4{ }^{\circ} \mathrm{C}$ for estimation of specific binding of $\mathrm{mAbs}$ to immobilized ovalbumin. Since $0.1 \%$ Twin 20 blocks the binding of PRIGs to antigens almost completely [17], in this way the concentration of specific mAbs can be accurately estimated despite the presence of certain amount of PRIGs in some studied aliquots.

After incubation of the studied solutions of $\mathrm{mAbs}$ and/or PRIGs during $1 \mathrm{~h}$ these solutions were removed from plate wells by shaking out, the plates were thoroughly washed with TBS and the amount of the bound immunoglobulins (PRIGs bound either to BSA or myoglobin and mAbs bound to ovalbumin) were estimated with ELISA. 
Determination of mAbs affinity. In order to estimate the affinity in interaction between either intact or TFE-treated mAbs and ovalbumin we used the method described by Friguet et al. (1985) [15]. In short, the samples of studied antibodies were mixed in $1: 1$ proportion with ovalbumin solutions of different concentrations (from $4 \cdot 10^{-7}$ to $6.25 \cdot 10^{-9} \mathrm{M}$ ) and incubated about $20 \mathrm{~h}$ at room temperature for reaching the state of equilibrium. Then the samples of antibody-antigen mixtures were transferred to plate covered with ovalbumin. The plate was incubated for $1 \mathrm{~h}$ at room temperature in order to estimate the amount of antibodies that were not blocked by ovalbumin after reaching equilibrium in antigenantibody reaction.

Then the results obtained in this way were used for the estimation of antibody affinities by two different methods. In the first case, we used Eq. (1) suggested by Stevens (1987) [16]:

$$
\sqrt{\frac{A_{0}}{A_{0}-A_{i}}}=\frac{K_{d}}{l_{i}}+1
$$

where $A_{0}$ is the well's color intensity for antibody samples, to which the antigen was not added, and $A_{i}$ is the color intensity in wells, to which the antigen was added. Here $K_{d}$ is the dissociation constant of antigen-antibody reaction, $K_{a}=1 / K_{d}\left(K_{a}\right.$ is the affinity constant), $l_{i}$ is the antigen concentration in mixture with antibodies.

From Eq (1) it is clear that $K_{\mathrm{d}}$ is equal to tangent in a graph of linear dependence $\sqrt{\frac{A_{0}}{A_{0}-A_{i}}}$ on $1 / l_{i}$.

As the second method we used Eq. (2) obtained by us earlier [17], which also allows estimating the affinity of bivalent antibodies:

$$
\alpha+\sqrt{\alpha^{2}+\alpha}=K_{a} l_{i},
$$

where $\alpha=\frac{A_{0}-A_{i}}{A_{i}}, K_{a}$ is the association constant of antigen-antibody reaction.

It is clear that if one uses Eq. (2), then $K_{a}$ is equal to tangent of the slope of the linear dependence $\alpha+\sqrt{\alpha^{2}+\alpha}$ on $l_{\mathrm{i}}$.

It is worth noting that Eqs. (1) and (2) being quite similar allows calculating identical values of affinity constant $K_{a}=1 / K_{d}$ based on absolutely presise $A_{i}$ and $A_{0}$ data. In practice, however, this may not happen. In addition in Eq. (1) the values in the left side is proportional to reverse values of concentration of competing antigen, but in Eq. (2) the left side of equation is proportional to direct values of antigen concentration. In this regard, if in the studied antibody sample there is a small fraction of those with affinity lower than the bulk, this cannot be detected with Eq. (1) as far as practically linear dependence between $\sqrt{\frac{A_{0}}{A_{0}-A_{i}}}$ and $\mathrm{l} / \mathrm{l}_{i}$ will be observed. This is because at high concentrations of competing anti-

gen $l_{i}$, the experimental points will be located very closely and the deviations from linearity could not be detected.

Alternatively if one uses Eq. (2) for estimation of $K_{a}$, then instead of linear dependence between $\alpha+\sqrt{\alpha^{2}+\alpha}$ and $l_{i}$ at high concentrations of competing antigen the convex curve will be obtained. If so, that will show the presence in the studied sample of not only the high-affinity but also of admixture of low-affinity antibodies. Thus, using Eq. (2) is preferable in many cases.

\section{Results and Discussion}

In order to study the effect of TFE on transformation of specific mAbs into nonspecific PRIGs or on the mAbs ability to bind antigen specifically, at first we determined TFE concentration range that does not produce any effect on the interaction between either PRIGs or mAbs and antigens. With that knowledge we would be safe to see that after treatment of mAbs with TFE dilution of the mixture of mAbs and TFE 100-200 times the residual TFE concentration will not influence $m A b s$ or PRIGs interaction with immobilized antigen.

Fig. 1, A presents the dependence of anti-OVA $m$ Abs binding to ovalbumin immobilized on plate on TFE concentration in mAbs samples. We observe that up to $1 \%$ concentration of TFE there is no decrease of antibody binding. If the TFE concentration is further increased we observed a decrease of mAbs binding to the antigen. Thus the TFE concentrations below $1 \%$ are quite acceptable for further evaluation of the mAbs binding to immobilized ovalbumin.

In order to determine how TFE takes influence on PRIGs binding to antigens, we first obtained PRIGs by incubation of anti-OVA mAbs with $5 \mathrm{M}$ $\mathrm{KSCN}$ solution at $25{ }^{\circ} \mathrm{C}$ during $5 \mathrm{~min}$. These are the conditions, which induce mAbs transformation into PRIGs [1]. Then these samples were mixed with 

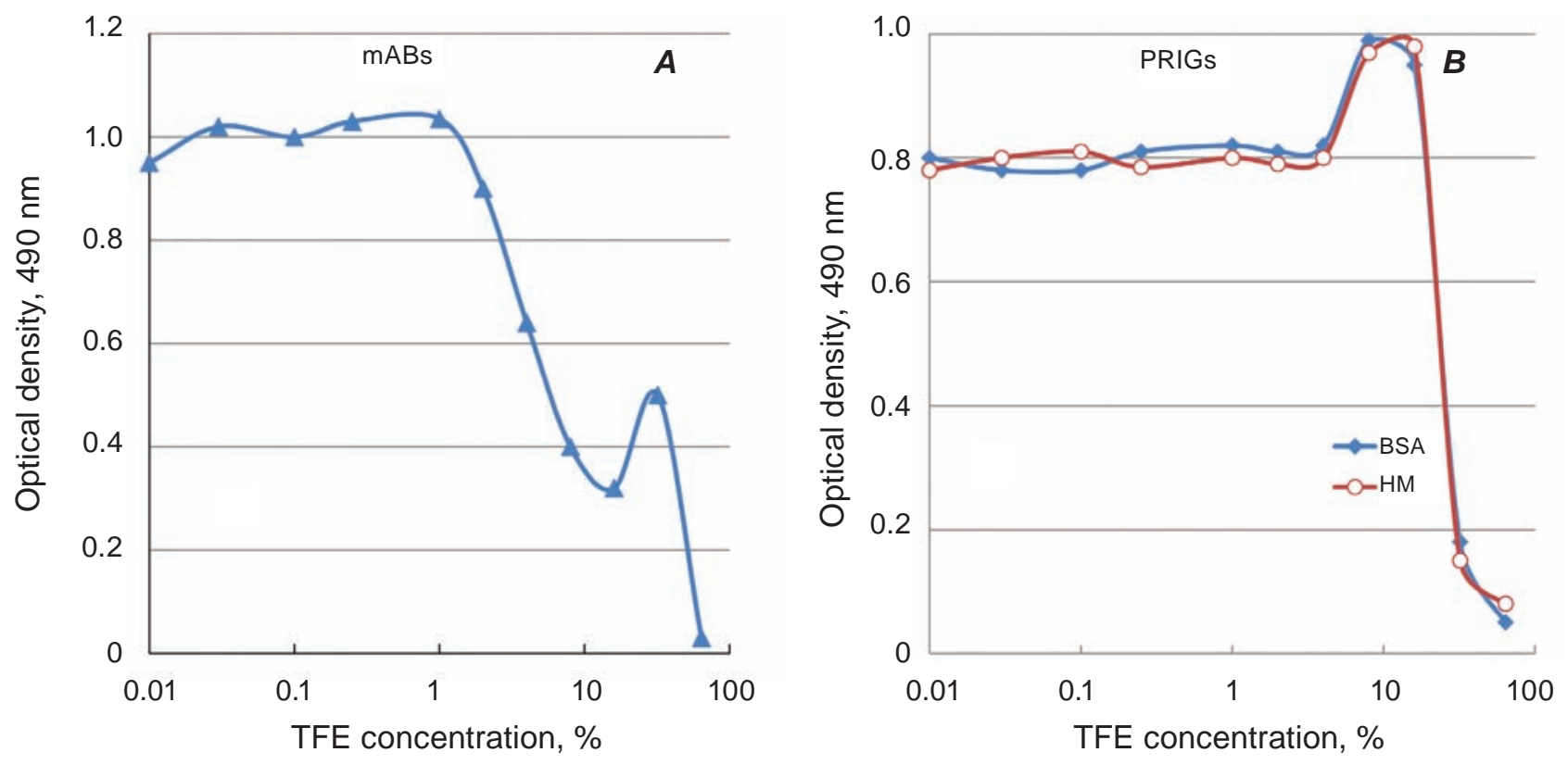

Fig. 1. Effect of TFE on the binding of mAbs (A) to immobilized ovalbumin or PRIGs (B) to immobilized BSA or horse myoglobin (HM)

different TFE concentrations and it was determined how TFE influences the nonspecific binding of the PRIGs to different antigens immobilized on a plate. It can be seen (Fig. 1, B) that up to $4 \%$ TFE did not decrease the level of PRIG binding to antigens. Thus, if the studied analyte containing different concentration of TFE is diluted in such a way that its concentration drops below $1 \%$, then the presence of TFE will not influence $\mathrm{mAbs}$ or PRIGs binding to immobilized antigen.

It can also be seen from Fig. $1, A$ and $B$ that at TFE concentrations higher than 30\% the binding of both mAbs and PRIG to antigen is essentially suppressed. Thus, it can be expected that TFE concentrations 30\% and higher result in such conformational changes of immunoglobulin Fv-regions which prevent the binding of both mAbs and PRIGs to the antigens.

On the next step, we studied the influence of $30 \%$ TFE on mAbs transformation into PRIGs. These experiments were performed at $25^{\circ} \mathrm{C}$ and at different incubation times. For this, mAbs or PRIGs samples were mixed with $30 \%$ solution of TFE, and the mixtures were incubated for different time (from $0.5 \mathrm{~min}$ to $15 \mathrm{~min}$ ) at $25^{\circ} \mathrm{C}$. Then the mixture was either 100 times diluted with PBS (for study PRIGs reactivity) or diluted 400 times with TBS (for studying mAbs reactivity). After that the samples in TBS were transferred to plates with immobilized ovalbumin and incubated for $1 \mathrm{~h}$ at $25^{\circ} \mathrm{C}$ for evaluating the activity of mAbs. The samples in PBS were transferred to plates with immobilized BSA or horse myoglobin and incubated during $1 \mathrm{~h}$ at $37{ }^{\circ} \mathrm{C}$ for evaluating PRIGs activity. After that, the amount of bound mAbs or PRIGs to the immobilized antigens was determined by ELISA.

Fig. 2, A shows the results of one of such typical experiments. We observe that the mAbs activity after incubation in 30\% TFE decreases gradually with time, which may be considered as the result of their inactivation or changing the conformation of antibodies Fv-region and their transformation into nonspecific PRIGs, as this happens, for example, when mAbs are treated with 3.5-5.0 M solution of KSCN [1]. However, if it were the case, the PRIGs activity should gradually increase, but according to Fig. 2, $B$ the dynamics of PRIGs activity changes in a more complicated way. This testifies to the differences in TFE action on specific antibodies and nonspecific PRIGs and suggests involving some other effects than the action of either solution of KSCN or extreme shift of $\mathrm{pH}$ values.

In line with these findings we decided to study the TFE effects on mAbs in more detail. We analyzed how the $30 \%$ TFE solution influences the ability of mAbs to interact both with correspondent antigen (ovalbumin) and with nonspecific antigen (horse myoglobin). It was expected that attaining by mAbs 
$A$

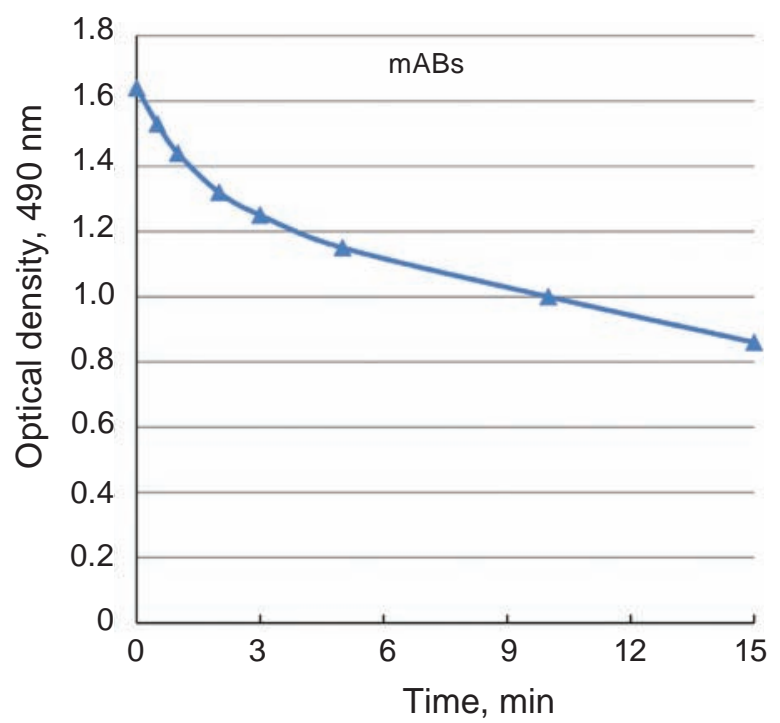

B

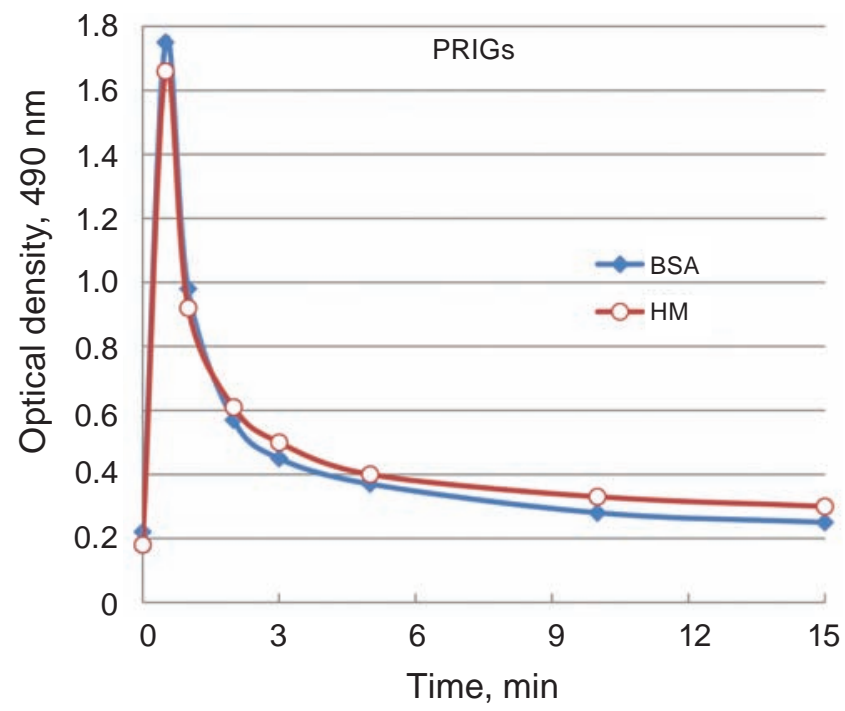

Fig. 2. Dynamics of the changing of the reactivity of $m A$ bs (against ovalbumin) and PRIGs (against BSA or horse myoglobin) if mAbs or PRIGs were incubated 0.5-15 min with $30 \%$ TFE at $25^{\circ} \mathrm{C}$

$A$

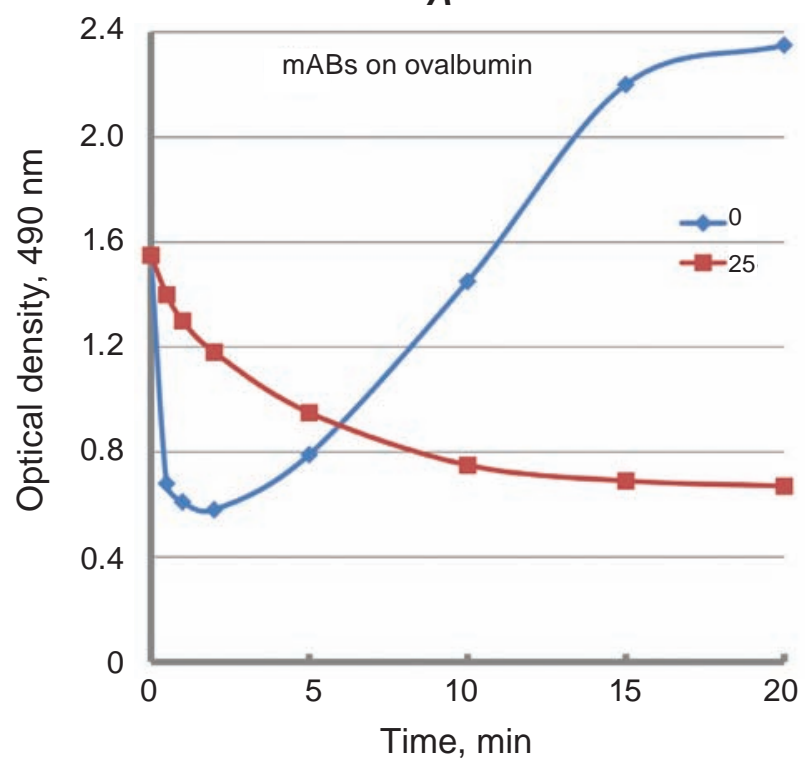

B

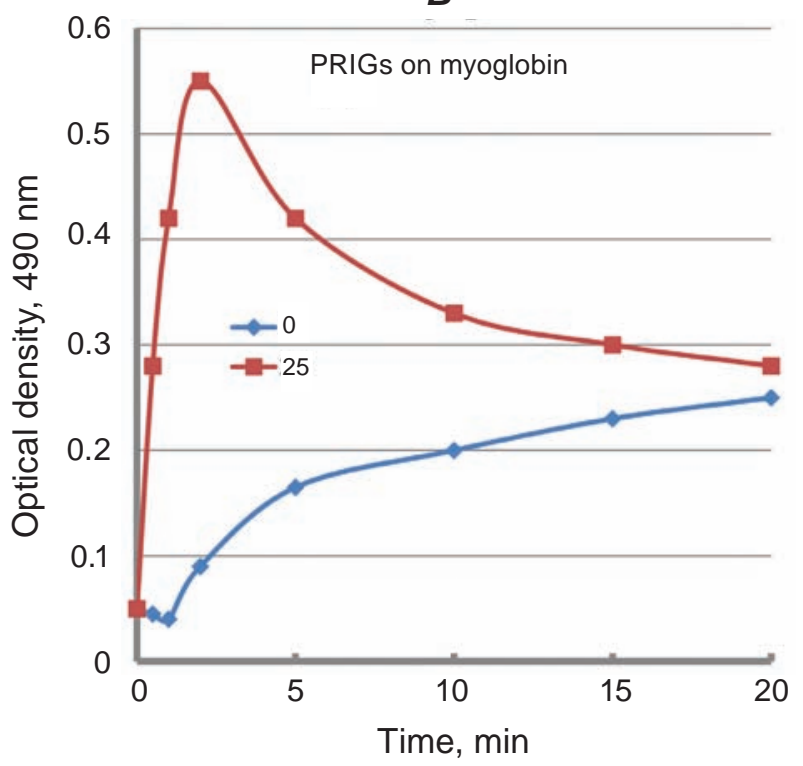

Fig. 3. Changing of specific and nonspecific reactivity of $m$ Abs against ovalbumin or horse myoglobin after antibody incubation in $30 \%$ TFE at $0^{\circ} \mathrm{C}$ or at $25^{\circ} \mathrm{C}$ during $0.5-20 \mathrm{~min}$

ability to bind nonspecifically horse myoglobin will show us the transformation of some part of specific antibodies into PRIGs.

Fig. 3 shows the results of these experiments. As it can be seen in Fig 3, A, after incubation of antibodies in $30 \% \mathrm{TFE}$ at $25{ }^{\circ} \mathrm{C}$ the reactivity of specific antibodies against ovalbumin gradually decreases during $20 \mathrm{~min}$, which can be interpreted as a result of the transformation of specific antibodies into PRIGs resulting in the change of its concentration and/or the rate of specific binding. The unexpected dynamics of appearance of high PRIGs activity in the first minutes of incubation of mAbs with 30\% TFE solution and then a decrease of this activity (Fig. 3, B) could be explained by two-step antibody transformation - first to PRIGs and then 
to denatured state and losing the ability to bind to horse myoglobin.

However, unlike the results obtained at $25^{\circ} \mathrm{C}$, at $0{ }^{\circ} \mathrm{C}$ the results were quite different (Fig. 3, A) showing the complexity of transformation mAbs to PRIGs. In these conditions mAbs activity first goes down and then starts to increase slowly. After 1520 min incubation it became equal or in some cases even exceeds the initial mAbs activity. It is hard to explain such dynamics of change of mAbs activity by the process of transformation of mAbs to PRIGs only. No doubt, the influence of TFE on conformation of antibodies is a more complex process than that observed on treatment of mAbs with chaotropic ions or sharp changes of $\mathrm{pH}$.

In order to study this process in more detail we studied the dynamics of changing the specific and nonspecific reactivity of $\mathrm{mAbs}$ after their treatment with different TFE concentrations at $0{ }^{\circ} \mathrm{C}$ and at $25^{\circ} \mathrm{C}$. Fig. $4, A$ and $4, B$ show the results of one of such experiments, in which the effect of TFE on mAbs was studied at different TFE concentration (2, 5, 10, 15, 25 and 30\%) within 0.5-40 min period. Then we studied the ability of such mAbs to interact either specifically (as antibodies) with ovalbumin or nonspecifically (as PRIGs) with horse myoglobin. It was found that even such a low TFE concentration as $2 \%$ at $0{ }^{\circ} \mathrm{C}$ still exerts well recorded influence on mAbs activity. Higher TFE concentrations are more efficient in their influence on mAbs binding with corresponding antigen and increasing the nonspecific PRIGs activity. Consider these changes in more detail.

It can be seen (Fig. $4, B$ ) that at $25^{\circ} \mathrm{C}$ the increase of TFE concentration up to $30 \%$ results in noticeable enhancement of the transformation of specific mAbs into nonspecific PRIGs during all time period of our study. Much less effect had 25\% solution of TFE but the tendency to increase PRIGs activity is the same. Further decrease of TFE concentration (to 20\% and less) demonstrates an interesting tendency: after a short-term notable increase of PRIG activity the process is stopped, at first it even slightly decrease and further the level of PRIGs activity remains almost on the same level. Of special interest is the fact that at quite different TFE concentrations the process of PRIGs increase is not monotonous but exhibits an oscillating nature. After about 10 minutes of observation these pulsations disappear and the kinetics proceeds in a smooth manner.
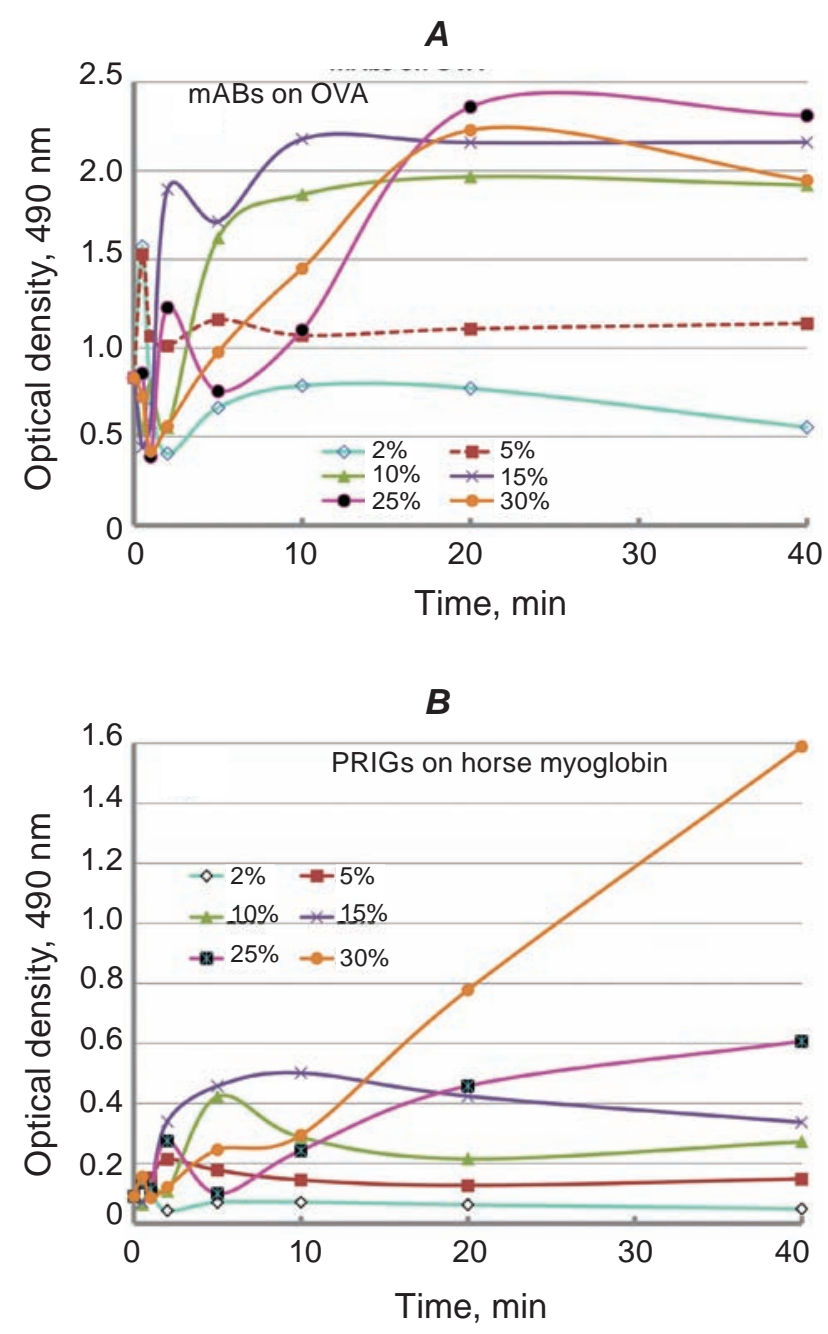

Fig. 4. Dynamic of the $m$ Abs reactivity against ovalbumin (A) and PRIGs reactivity (B) against horse myoglobin after incubation of $m A$ bs with different concentration of TFE at $0^{\circ} \mathrm{C}$ during 0.5-40 $\mathrm{min}$

Exact nature of these pulsing curves is not known, but we can suggest that the process of mAbs conformational change is involved and it proceeds oscillatory in view of TFE ability not only to change the conformation of Fv region but also to stabilize some segments of polypeptide chain. As a result, the conformational changes in the Fv region follow steps, on which the PRIGs activity first increases and then gradually decreases. This process finishes already after 5-10 min and then the PRIGs activity achieves the plateau level.

Meantime the most unexpected changes in mAbs activity occur at $0{ }^{\circ} \mathrm{C}$ (Fig. $4, A$ ). Here also the mAbs activity first changes in oscillating manner and it reaches the plateau level after 20-30 min. 
It can be seen that specific mAbs reactivity at first dropped down very fast and then the reactivity gradually increased. The effect of TFE on mAbs is similar at TFE concentration in the range of $10-30 \%$. Much less effect was observed at TFE concentrations 2 and 5\%. In this case the level of mAbs activity also reaches plateau (after 10-20 min of incubation) but it demonstrates little difference from mAbs activity without TFE treatment.

The most unexpected and probably the most important of discovered regularities is the fact that the mAbs activity treated with $10-30 \%$ TFE at $0{ }^{\circ} \mathrm{C}$ during 30-40 $\mathrm{min}$ is in some experiments 1.2-1.5 times higher than the initial level of mAbs activity. The question is, what is the reason of such an increase? One can suppose that such increase of mAbs activity can be either due to the change of antibody properties and the resulting change in interaction parameters with antigen or because of the increase of mAbs concentration in the TFE-treated samples.

In order to elucidate, what of these possibilities is more probable, we studied the affinity of interaction between ovalbumin and mAbs either nontreated or treated by $25 \%$ solutions of TFE at $0{ }^{\circ} \mathrm{C}$ during either $2 \mathrm{~min}$ or $40 \mathrm{~min}$. In so doing we used two methods of determining the antibodies affinity as it was described in Materials and Methods. One of this methods allows not only measuring the affinity but also revealing if the studied sample of antibodies is homogeneous or it consists of two or more antibody types differing in affinities.

Fig. 5 presents the linear functions (A) obtained on titration of the studied samples of mAbs (control and treated by TFE at $0{ }^{\circ} \mathrm{C}$ ) and also the curves of blocking these samples of mAbs (B) by different ovalbumin concentrations. Since on titration of mAbs samples the liner dependences are obtained in all three cases, this witnesses for the presence of proportionality between antibodies concentration and the color (optical density) in the plate wells obtained by ELISA. Thus, these data demonstrate that in our experiments the values of optical density can be used for calculation of the parameters for antigenantibody interaction instead of antibody concentrations.

From Fig. 5, $A$ it is also clear that the activity of mAbs samples treated for $40 \mathrm{~min}$ by 25\% TFE at $0{ }^{\circ} \mathrm{C}$ is somewhat higher than in control samples. As usual, a sample of mAbs preincubated for $2 \mathrm{~min}$ in $25 \%$ TFE at $0{ }^{\circ} \mathrm{C}$ had a much lower activity than in control. However, the blocking of all three antibody
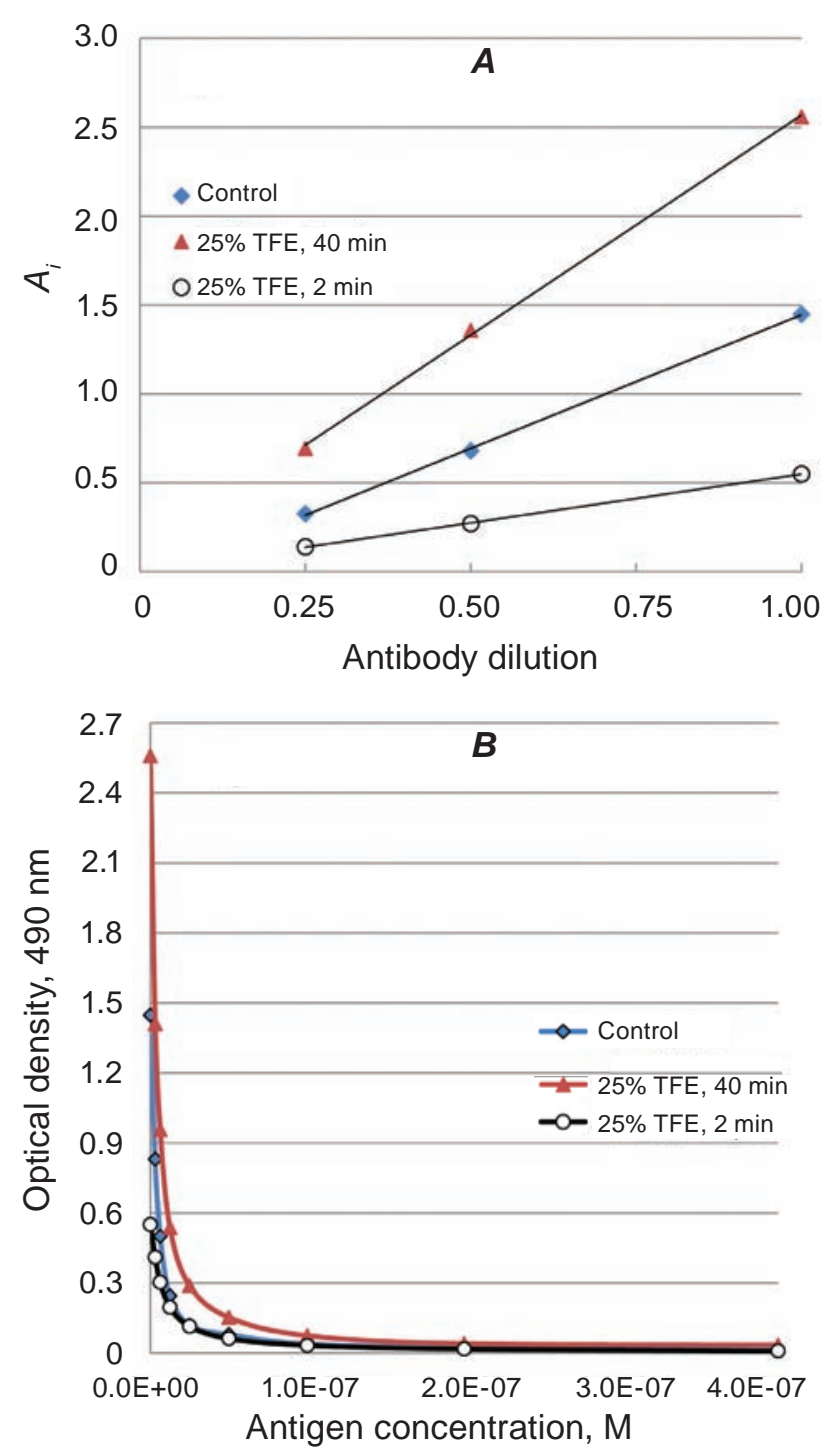

Fig. 5. A - Titration of $m A b s$ before (control) and after $\mathrm{mAbs}$ incubation either $2 \mathrm{~min}$ or $40 \mathrm{~min}$ in $25 \%$ TFE solution at $0{ }^{\circ} \mathrm{C} ; \boldsymbol{B}$ - Relation between concentration of competing antigen $l_{i}$ and values of $A_{i}$, obtained by ELISA. A values are proportional to the concentration of "free" antibodies (i.e. antibodies, one or two paratopes of which are not blocked by the antigen) in mAbs-antigen mixture after reaching of the equilibrium

samples by different ovalbumin concentrations was quite similar. The use of these data for constructing the graphs of $\sqrt{\frac{A_{0}}{A_{0}-A_{i}}}$ on reverse ovalbumin concentration $1 / l_{\mathrm{i}}$, (Fig. $6, A$ ) or $\alpha+\sqrt{\alpha^{2}+\alpha}$ (where $\alpha=\frac{A_{0}-A_{i}}{A_{i}}$ ) on ovalbumin concentration $l_{i}$ (Fig. 6, $B$ ), allows obtaining linear dependences, the angle 

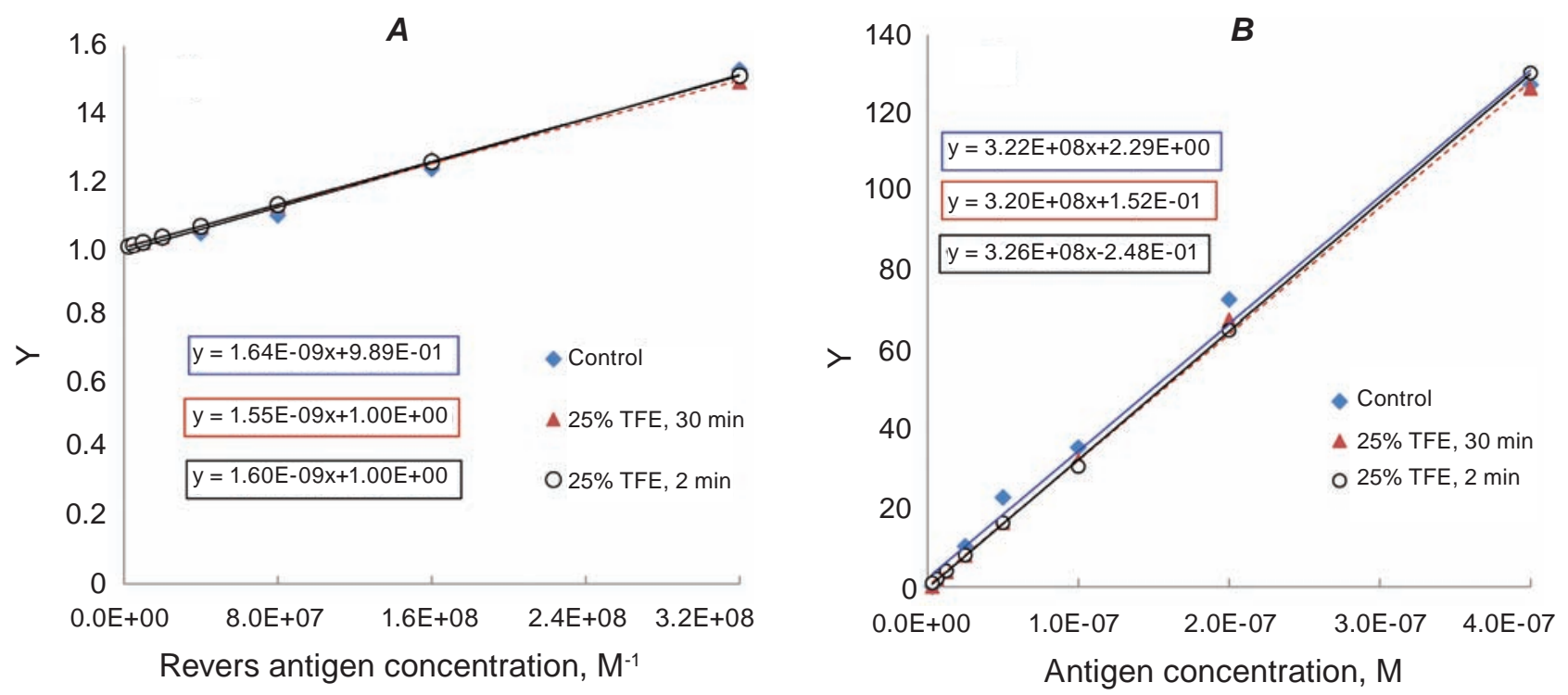

Fig. 6. Evaluation of the affinity of anti-ovalbumin mAb before (control) and after mAbs incubation in 25\% solution of TFE at $0{ }^{\circ} \mathrm{C}$ during 2 min or 40 min. $A: Y=\sqrt{\frac{A_{0}}{A_{0}-A_{i}}}$ (Stevens equation, [19]). B: $Y=\alpha+\sqrt{\alpha^{2}+\alpha}$, where $\alpha=\frac{A_{0}-A_{i}}{A_{i}}$ (our equation, [20])

of decline of which in the first case is equal to dissociation constant $K_{d}=1 / K_{a}$, and in the second case it is equal to the affinity constant $K_{a}$ (see Materials and Methods).

The fact that for TFE samples intact and treated by $25 \%$ in Fig. $6, A$ the linear functions were obtained witnessing for homogeneity of antibodies in three studied samples, i.e. the antibodies were homogeneous and there was no appreciable amount of antibody admixtures with different affinities. Also, these linear functions were practically superimposed, which witnesses for similar antibody affinity before and after $25 \%$ TFE treatment at $0{ }^{\circ} \mathrm{C}$ during $2 \mathrm{~min}$ or $40 \mathrm{~min}$. When we used Stevens Eq. (1), $K_{d}$ was found to be equal to $1 \cdot 64 \cdot 10^{-9} \mathrm{M}$ for control sample of mAbs, $1.55 \cdot 10^{-9} \mathrm{M}$ for 40 min TFE-treated sample, and $1.60 \cdot 10^{-9} \mathrm{M}$ for TFE-treated sample during 2 min.

Even smaller differences between intact and treated samples of mAbs were found (Fig. 6, B) on application of Eq. (2), namely: $K_{a}=3.22 \cdot 10^{8} \mathrm{M}^{-1}$ for control antibodies, $K_{a}=3.26 \cdot 10^{8} \mathrm{M}^{-1}$ for TFE-treated mAbs during $2 \mathrm{~min}$, and $K_{a}=3.20 \cdot 10^{8} \mathrm{M}^{-1}$ for mAbs treated 40 min with $25 \%$ TFE at $0{ }^{\circ} \mathrm{C}$. Thus, treatment of mAbs with $25 \% \mathrm{TFE}$ at $0{ }^{\circ} \mathrm{C}$ for $2 \mathrm{~min}$ or $40 \mathrm{~min}$ did not appreciably change the affinity of the interaction between mAbs and correspondent antigen. Thus, a conclusion can be derived that the decrease of mAbs activity after $2 \mathrm{~min}$ or the increase after 40 min treatment by $25 \%$ TFE at $0{ }^{\circ} \mathrm{C}$ mainly can be due not to the affinity but to changing of antibody concentration.

The most unexpected for us was the fact that after initial sharp drop of specific antibody activity the restoration of this activity develops in time. Of special interest is the fact that in some experiments it was obtained that after incubation of mAbs in 25\% TFE at $0{ }^{\circ} \mathrm{C}$ during 30-40 min their activity even exceeds the control level (Fig. 4). This fact witnesses that within initial anti-ovalbumin mAbs pool there may be the fraction of mAbs the conformation of Fvregion of which does not allow their paratop formation that is complementary to corresponding antigen and, as a consequence, does not allow binding to this antigen. But under the TFE influence the re-arrangement in binding site occurs leading to appearing of antibody activity against ovalbumin. If it is so, then it can be suggested that in pool of anti-ovalbumin mAbs may exist two (or even more) relatively stable forms of antibodies with their paratopes, which are complementary to structurally different epitops. Further experiments will show if that can be the case or it is possible to use another explanation of this phenomenon. 


\section{ВПЛИВ ТРИФТОРЕТАНОЛУ НА РЕАКТИВНІСТЬ АНТИТІЛ ПО ВІДНОШЕННЮ ДО ВІДПОВІДНОГО АНТИГЕНУ АБО ДО СЕРОЛОГІЧНО НЕСПОРІДНЕНИХ АНТИГЕНІВ}

\author{
С. А. Бобровник, М. О. Демченко, \\ С. В. Комісаренко
}

\author{
Інститут біохімії ім. О. В. Палладіна \\ НАН України, Київ; \\ e-mail: s-bobrov@ukr.net
}

Здатність специфічних антитіл за певних умов втрачати свою специфічність і перетворюватись в поліреактивні імуноглобуліни (ПРІГ) є дуже цікавим феноменом. В цій роботі ми продемонстрували, що 2,2,2-трифторетанол (ТФЕ) є одним із факторів, які можуть впливати як на здібність моноклональних антитіл специфічно взаємодіяти з відповідним антигеном (овальбуміном), так і на їх трансформацію в ПРІГ, що здатні неспецифічно зв'язуватися 3 різноманітними антигенами. Така зміна реактивності антитіл під впливом ТФЕ $\epsilon$ нелінійною функцією, яка залежить не тільки від концентрації ТФЕ, але й від часу і температури інкубації. Показано, що при кімнатній температурі (біля $25{ }^{\circ} \mathrm{C}$ ) специфічні антитіла під впливом 30\% ТФЕ трансформуються в ПРІГ. Проте при $0{ }^{\circ} \mathrm{C}$ процес зміни активності антитіл $є$ складнішим.

$$
\begin{array}{lcr}
\multicolumn{1}{c}{\text { Кл ю ч в в }} & \multicolumn{1}{c}{\text { слов в: }} & \text { специфічні } \\
\text { моноклональні } & \text { антитіла; } & \text { поліреактивні } \\
\text { iмуноглобуліни; } & \text { взаємодія } & \text { антиген-антитіло; } \\
\text { 2,2,2-трифторетанол; афінність антитіл. }
\end{array}
$$

\section{ВЛИЯНИЕ ТРИФТОРЭТАНОЛА \\ НА РЕАКТИВНОСТЬ \\ АНТИТЕЛ В ОТНОШЕНИИ СООТВЕТСТВУЮЩЕГО АНТИГЕНА \\ ИЛИ СЕРОЛОГИЧЕСКИ НЕРОДСТВЕННЫХ АНТИГЕНОВ}

\author{
С. А. Бобровник, М. А. Демченко, \\ С. В. Комисаренко
}
Институт биохимии им. А. В. Палладина НАН Украины, Киев; e-mail: s-bobrov@ukr.net

Способность специфичных антител при определённых условиях терять свою специфичность и превращаться в полиреактивные иммуноглобулины (ПРИГ) является чрезвычайно интересным феноменом. В статье мы продемонстрировали, что 2,2,2-трифторэтанол (ТФЭ) является одним из факторов, которые могут влиять как на способность моноклональных антител специфично взаимодействовать с соответствующим антигеном (овальбумином), так и на их трансформацию в ПРИГ, которые способны неспецифически связываться с разнообразными антигенами. Такое изменение реактивности антител под влиянием ТФЭ является нелинейной функцией, которая зависит не только от концентрации ТФЭ, но и от времени и температуры инкубации. Показано, что при комнатной температуре (около $25^{\circ} \mathrm{C}$ ) специфичные антитела под воздействием 30\% ТФЭ трансформируются в ПРИГ. Однако при $0{ }^{\circ} \mathrm{C}$ процесс изменения активности антител является более сложным.

К л ю че в ы е с л о ва: специфичные моноклональные антитела; полиреактивные иммуноглобулины; взаимодействие антиген-антитело; 2,2,2-трифторэтанол; аффинность антител. 


\section{References}

1. Bobrovnik SA. Activation of "silent" antibodies and their interaction with antigens. Ukr Biokhim Zhurn. 1990; 62(5): 86-89. (In Russian).

2. Bouvet JP, Stahl D, Rose S, Quan CP, Kazatchkine MD, Kaveri SV. Induction of natural autoantibody activity following treatment of human immunoglobulin with dissociating agents. J Autoimmun. 2001; 16(2): 163-172.

3. Bouvet JP, Quan CP, Dighiero G. Polyreactivity is not an artefact. J Immunol Methods. 2001; 254(1-2): 199-201.

4. Bobrovnik SA. Polyreactive immunoglobulins: molecular properties and functions. Comments Mol Cell Biophys. 1999; (9): 323-356.

5. Gunti S, Kampylafka EI, Tzioufas AG, Notkins AL. Polyreactive antibodies in the circulation of patients with systemic lupus erythematosus. Lupus. 2015; 24(14): 1567-1569.

6. Bobrovnik SA, Lavrenchuk GI, Benkovska NP, Chorna NE. The influence of polyreactive antibodies on tumor cell proliferation. Exp Oncol. 1998; 20(3-4):2 17-222.

7. Rezaei-Ghaleh N, Amininasab M, NematGorgani M. Conformational changes of alphachymotrypsin in a fibrillation-promoting condition: a molecular dynamics study. Biophys J. 2008; 95(9): 4139-4147.

8. Julien O, Mercier P, Crane ML, Sykes BD. The effect of the cosolvent trifluoroethanol on a tryptophan side chain orientation in the hydrophobic core of troponin C. Protein Sci. 2009; 18(6): 1165-1174.

9. Khemtémourian L, Sani MA, Bathany K, Gröbner G, Dufourc EJ. Synthesis and secondary structure in membranes of the Bcl-2 antiapoptotic domain BH4. J Pept Sci. 2006; 12(1): 58-64.
10. Sönnichsen FD, Van Eyk JE, Hodges RS, Sykes BD. Effect of trifluoroethanol on protein secondary structure: an NMR and CD study using a synthetic actin peptide. Biochemistry. 1992; 31(37): 8790-8798.

11. Santiveri CM, Pantoja-Uceda D, Rico M, Jimenez MA. Beta-hairpin formation in aqueous solution and in the presence of trifluoroethanol: a ${ }^{1} \mathrm{H}$ and ${ }^{13} \mathrm{C}$ nuclear magnetic resonance conformational study of designed peptides. Biopolymers. 2005; 79(3): 150-162.

12. Calamai M, Chiti F, Dobson CM. Amyloid fibril formation can proceed from different conformations of a partially unfolded protein. Biophys J. 2005; 89(6): 4201-4210.

13. Pallarès I, Vendrell J, Avilés FX, Ventura S. Amyloid fibril formation by a partially structured intermediate state of alpha-chymotrypsin. $J \mathrm{Mol}$ Biol. 2004; 342(1): 321-331.

14. Bobrovnik SA. Mechanisms of interaction of polyreactive immunoglobulins and protein antigens. Ukr Biokhim Zhurn. 2002; 74(2): 3744. (In Russian).

15. Friguet B, Chaffotte AF, Djavadi-Ohaniance L, Goldberg ME. Measurements of the true affinity constant in solution of antigen-antibody complexes by enzyme-linked immunosorbent assay. J Immunol Methods. 1985; 77(2): 305-319.

16. Stevens FJ. Modification of an ELISA-based procedure for affinity determination: correction necessary for use with bivalent antibody. Mol Immunol. 1987; 24(10): 1055-1060.

17. Bobrovnik SA. Determination of antibody affinity by ELISA. Theory. J Biochem Biophys Methods. 2003; 57(3): 213-236.

Received 23.01.2018 